\title{
"Be I a devil, yet God may pity me": Rereading Marlowe's The Tragical History of Doctor Faustus from Islamic Perspective
}

\author{
Mohammad Kaosar Ahmed, PhD
}

Associate Professor, Department of English Language and Literature, International Islamic University Chittagong, Bangladesh

\begin{abstract}
Marlowe's Doctor Faustus has kept on catching the consideration of modern and postmodern pundits. For a very long while Faustian commentators are isolated between those two who see the play reflecting intense and steady religious standpoint, and the individuals who see the play as antireligious. This sharp resistance between the standard and heterodox perspectives partially mirrors the clashed life of the writer himself, who started his concise adulthood as a philosophy student and finished it as a famous figure blamed for agnosticism. This paper holds the perspective of the prior gathering of commentators contending that the concentration of deciphering this play ought to be religious. This article will endeavor to dissect the play from the perspective of Islam. Islam has something critical to say in regards to human nafs (mind), the everlasting clash between good and evil; friendship, and repentance and salvation.
\end{abstract}

Keywords- Nafs, Ilham, Waswasa, Repentance, Salvation.

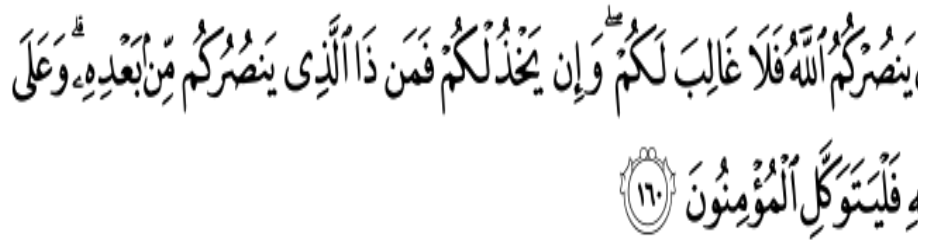

If Allah helps you, none can overcome you: If He forsakes you, who is there, after that, that can help you? in Allah, then, Let believers put their trust. (The Quran 3: 160)

\section{INTRODUCTION}

1.1 Background and Objective:

Previously I have worked with the textbook writing project of IIIT BD Chapter and contributed two chapters in the book titled Reading Shakespeare from Islamic Perspective. In that book I have argued that European discourses affect not only our day to day activities but also our mode of thinking or interpretations. Muslim students' familiarity with these Eurocentric modes of analysis ultimately results in intellectual mimicry (Ahmed, "The Turn to Islamic Ways" 3). Many students of English literature are unaware of the fact that Islam also has a complete worldview distinct fro $m$ the European worldview. The Muslim ummah needs to be aware of this intellectual destruction and re/deconstruct their pedagogy of reading or teaching European literature.

We can do so by deconstructing the western construct of the meaning of the literary texts. In my earlier works I have proposed that Muslim readers require achieving Islamic Critical Conscientization which will help us to have an indepth understanding of the Islamic worldview (Ahmed, "Islamic Discourse in Shakespearean Study" 17-18). This paper is a sample of what we mean by Islamic discourse and the place of western literature in it.

1.2 Research Methodology

Qualitative research methodology of Narrative analysis and Content Analysis were used in this research.

1.3 Research Questions:

The research addresses the following questions while analyzing the play:

i. What does Islam say about nafs (mind)?

ii. What is the Islamic notion of the cosmic battle between Good and evil?

iii. How does Islam define friendship?

iv. Is there any crime in Islam that is too big to be forgiven?

\section{FAUSTUS: FROM A HUMAN TO AN ACCURSED CREATURE}

A Wittenberg researcher, Faustus is traditional to start with, and after that he rejects all the religious lessons and winds up plainly radical. A prototypical renaissance man, Faustus 
is negligible and battling against medieval expert. He is a sort of masterless man, however Faustus discovers his lord when he signs contract with Lucifer, the father of all renegades. Dr Faustus has been trespassed from three points of view - the wrongdoing of religion, of established belief system and that of logic; and has trespassed on pondering as a piece of the fiends design or plot. Evil powers know well the limit of wrongdoing and they induce Faustus to move well ordered from a human to an accursed creature. His obliviousness and the devils' cunningness pave the ways to his final damnation.

When we initially meet Faustus, he is a man who is disappointed with his examinations in rationalizations, law, medicine, and divinity. Despite the fact that he is the most splendid researcher on the planet, his investigations have not brought him fulfillment, and he is discouraged about the impediments of human learning. So as to fulfill his hunger for more prominent information, he chooses to try in magic. He needs to rise above the obligations of typical hu man life and find the statures past. One may state that he needs to have supernaturalqualities.

Faustus will pitch his spirit to the demon under the terms of an agreement by which he will get twenty-four years of administration from Mephistophilis and, toward the fin ish of this time, will surrender his spirit to Lucifer. At first he is possibly an awesome man who wants to perform things useful for mankind, yet because of his eagerness to trade his spirit for a couple of years of delight, he starts to sink toward obliteration. He enables his forces to be decreased to performing absurd traps and to fulfilling his physical cravings.

At different circumstances all through the show, Faustus does stop and consider his difficulty and goes to the skirt of contrition. He regularly ponders apology, yet he intentionally stays lined up with Mephistophilis and Lucifer, and neverfinds a way to acquire absolution.

Before the ending of the show, when he is sitting tight for his condemnation, he justifies his refusal to swing to God. All through the show, inward and outer powers recommend that Faustus could have swung to God and could have been excused. In the last scene, the scholars need Faustus to make an endeavor to look for the absolution of God, however Faustus justifies that he has lived against the ways of God, and he tries to summon God's pardoning until the presence of the demons. By at that point, he can just shout out in distress and loathsomeness at his last destiny.

\section{NAFS IN ISLAMIC DISCOURSE}

Marlowe's famous work Dr Faustus is about a scholar's bargaining with the Lucifer in exchange of his nafs and the play leaves us with the protagonist's nafs's (soul) last night struggle which he goes in a discourse of anguish and yearning, amid which Faustus sees what paradise implies, however denies or can't swing to God. He is dragged shouting to hellfire naming his old confederate in a tone which may be perused as hatred, fear, acceptance, or every one of the three together.

Nafs has got two implications in Islamic discourse. First, it implies the powers of anger and sexual appetite in an individual and this is the utilization for the most part found among the general population of tasawwuf [sufis], who take "nafs" as the far reaching word for all the fiendishness.

The second importance of nafs is the spirit, the individual in all actuality, his self and his individual. It is depicted contrastingly as indicated by its diverse states. In the event that it expects serenity under charge and has expelled from itself the aggravation caused by the assault of enthusiasm, it is called "the fulfilled soul" (al-nafs al-mutma'inna). In its initial meaning the nafs does not visualize its arrival to God since it has kept itself a long way from Him: such a nafs is from the gathering of shaytan. Be that as it may, when it doesn't accomplish placidness, yet sets itself against the adoration for interests and questions it, it is called "the selfdenouncing soul" (al-nafs al-lawwama), in light of the fact that it censures its proprietor for his disregard in the love of his lord... On the off chance that it surrenders all dissent and surrenders itself in all out compliance to the call of interests and shaytan, it is named "the spirit that urges insidious" (alnafs al-ammara bi al-su') which could be taken to allude to the conscience in its initially meaning. In Dr Faustus we perceive how the hero's nafs shakes like a pendulum frame the condition of al-lawwama to al-ammara and the other way around. Once being reprimanded by al-lawwama he says "Be I a devil, yet God may pity me/ Yea, God will pity me if I repent"; minutes after the fact he turns into a slave of al-ammara and finishes "I am resolv'd, Faustus shall not repent". This moving province of Faustus impels us to brood over the Islamic notion of the cosmic battle between good and evil.

\section{DIAGNOSING HUMAN NATURE AND THE COSMIC BATTLE BETWEEN GOOD AND EVIL}

Dr. Faustus represents the constant battle between good and evil. Consistently, we are confronted choosing between the 
two, regardless of the possibility that there appears as though there is no arrangement. Faustus speaks to those that stoop to a lower level so as to get what they need. The Good Angel and the Evil Angel are the morals that draw the Faust's spirit separated, constraining him to settle on a choice that can influence his future. The story Dr. Faustus is an awesome case of how one wrong choice can cause an everlasting burn.

The battle amongst good and evil is a perpetual clash that has been progressing all through mankind's history. It has been unfurling from time of the first man and woman, Adam and Eve, as prove by the emotional standoff between their two youngsters, Abel and Cain. Abel was dependably in strife with his sibling, Cain. Both tried to love Allah, and both were made a request to render a yield. Be that as it may, affected by Satan, Cain picked as his blessing the most exceedingly terrible, most unhealthy sheep in his rush. Abel introduced his best yearling. Abel's give up was acknowledged, yet Cain's was rejected. Out of overpowering jealousy, Cain slew Abel. As to, Allah says:
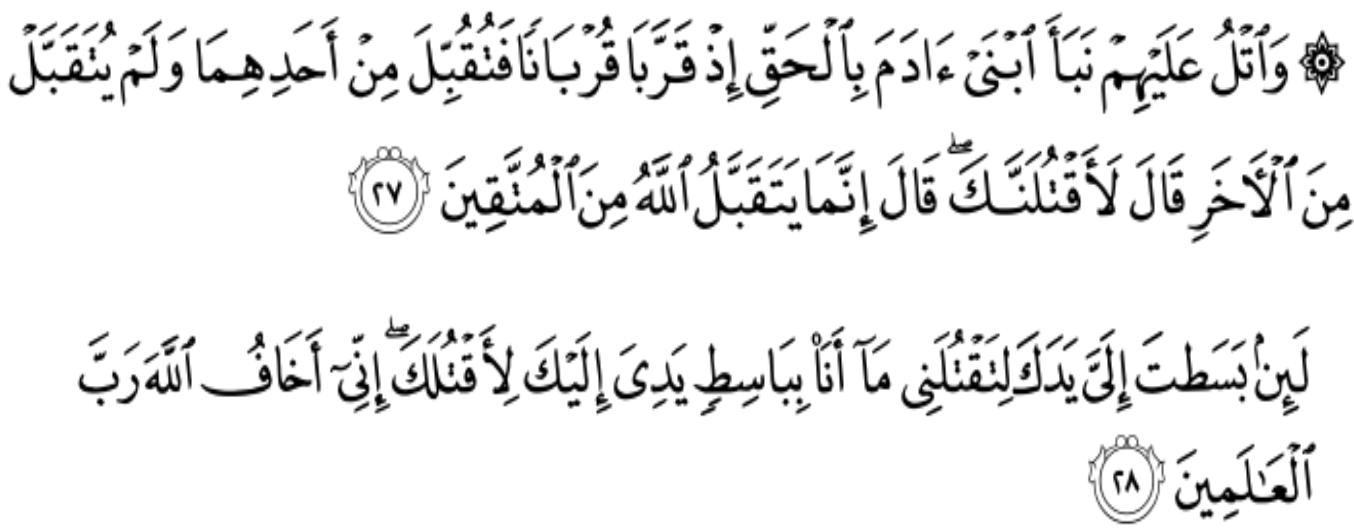

Recite to them the truth of the story of the two sons of Adam. Behold! they each presented a sacrifice (to Allah): It was accepted from one, but not from the other. Said the latter: "Be sure I will slay thee." "Surely," said the former, "Allah doth accept of the sacrifice of those who are righteous. If thou dost stretch thy hand against me, to slay me, it is not for me to stretch my hand against thee to slay thee: for I do fear Allah, the cherisher of the worlds". (The Quran 5:27-28)

Through this one sees Abel's immaculateness of heart and his resistance for his sibling. All the more significantly, it demonstrates his acknowledgment. Acknowledgment is a significant idea, since it goes a long ways past unimportant resistance. When we say we endure somebody, we imply that we endure his weaknesses and flaws. To acknowledge somebody is to recognize his entitlement to act naturally, withholding both judgment and feedback. It speaks to a higher condition of accommodation to Divine $\mathrm{W}$ ill and issues from a position of genuine love, making it an uncommon quality without a doubt.

The connection amongst good and evil has dependably charmed individuals, and it is one of the focal standards whereupon religious principle and conviction frameworks are manufactured. Religion assumes a focal part in revealing insight onto these unique ideas, and Islam is no exemption. Is lam offers an entire picture in clarifying good and evil.

\subsection{Ilham vs Waswasa}

The dramatization of the unending conflict between good and evil has primarily been shown by the presentation of the Good Angel (what Islamic discourse terms as ilham) and Band Angel (what Islamic discourse terms as waswasa). Imama Gazaly in his Ihya Ulmuddin opines that human musings that mix one's desire are of two sorts: praiseworthy, known as "inspiration" (ilham), and blameworthy, and that is known as "whispering" (waswasa). The heart is claimed commonly by a shaytan and a blessed angel. Gazaly proceeds with that the blessed messenger remains for an animal which God has made for the flooding of advantage, the bestowal of information, the uncovering of truth, the guarantee of reward, and the requesting of the great. Gazali wraps up that the shaytan signifies a creature whose dealing is to be against all this -Waswasa against ilham, shaytan against angel, success (tawfiq) against disappointment (khidhlan). Gazaly's analysis has a direct reference to a hadith that says: 
The Prophet (s) said: "There are two impulses in the soul, one from an angel which calls towards good and confirms truth; whoever finds this let him know it is from God and praise Him. Another impulse comes from the enemy which leads to doubt and denies truth and forbids good; whoever finds this, let him seek refuge in God from the accursed devil." Then he recited the verse: "The devil shows you fear of poverty and enjoins evil upon you" (2:268) [qtd in Gazaly].

Hasan al-Basri said: "Two considerations meander over the spirit, one from God, one from the devil. God demonstrates benevolence on a hireling who settles at the prospect that originates from Him. He grasps the possibility that originates from God, while he battles against the one from his foe. To show the heart's shared fascination between these two powers the Prophet (s) stated: "The heart of a believer lies between two fingers of the Merciful" (Sunan Ibn Majah Vol. 5, Book 34, Hadith 3834). The fingers represent change and faltering in the heart. On the off chance that man pursues the directs of resentment and hunger, the domain of shaytan shows up in him through inactive interests [hawa] and his heart turns into the settling spot and compartment of shaytan, who benefits from hawa. On the off chance that he battles with his interests and does not give them a chance to overwhelm his nafs, impersonating in this the character of the holy messengers, around then his heart turns into the resting-spot of heavenly attendants and they land upon it. Abdullah b. Mas'ud

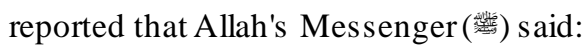

There is none amongst you with whom is not an attache from amongst the jinn (devil). They (the Companions) said: Allah's Messenger, with you too? Thereupon he said: Yes, but Allah helps me against him and so I am safe from his hand and he does not command me but for good. (Sahih Muslim Book 39, Hadith 6757)

The shared repulsing of the fighters of the holy messengers and the fallen angels is consistent in the fight over the heart, until the heart is vanquished by one of the opposite sides which sets up its country and settles there... Furthermore, most hearts have been seized by the warriors of shaytan, who fill them with the murmurs that consider one to adore this passing world and disregard the next.

We see the primary appearance of ilham and waswasa toward the beginning of the Scene 5, in which Faustus truly consents to his arrangement with Mephastophilis. They chat on the other hand, each putting one side of dispute. Here, the Evil Angel (waswasa) allures Faustus with the power he is ensured by the Devil, while the Good Angel (ilham) causes him to recollect the dangers of his lead. When they return, at the beginning of the Scene 7 , they continue in these parts, with the Evil Angel (waswasa) bracing Faustus' as surance.

The Angels appear, in a similar scene, at the point where Faustus comprehends that there are a couple of requests that Mephastophilis won't answer and that he has accomplished the limits of what he can get from his malicious

arrangement. As on past occasions, the Angels are seen at a crucial moment, when Faustus is wavering:

Evil Angel: Too late.

Good Angel: Never too late, if Faustus can repent.

Evil Angel: If thou repent, devils shall tear thee in pieces.

Good Angel: Repent, and they shall never raise thy skin.

Exeunt [ANGELS]

Faustus: $\quad$ Ah Christ my Saviour, seek to save

Distressed Faustus'

soul.

Scene 7, 75-80

Faustus reacts to ilham at a phase when it is past the point of no return and he seems, by all accounts, to be debilitating to such a degree, to the point that Mephas tophilis acquires Lucifer and Beelzebub to help Faustus to remember his deal; and he is constrained to surrender to waswasa.

Ilham comes to him as Old man as well, yet dismal to state, he doesn't regard to the old man. It is noteworthy to take note of that ilham does not come here as blessed messenger but rather as a kindred individual and one who has carried on with his life as per religious statutes.

Ilham in the appearance of the Old Man presents to Faustus various admonitions and messages:

the 'sweet path ...

That shall conduct thee to celestial rest (Scene 12, 36-37)

He helps Faustus to remember the foul idea of his trans gressions:

thy most vile and loathsome filthiness,

The stench whereof corrupts the inward soul (Scene 12, 40-41)

Conversely, he also helps Faustus to remember the redemptive intensity of religion: 
mercy, Faustus, of thy saviour sweet,

Whose blood alone must wash away thy guilt

(Scene 12, 44-45)

I see an angel hovers o'er thy head,

And with a vial full of precious grace,

Offers to pour the same into thy soul(53-55)

More than once he utilizes the word 'sweet', to allude both to God's effortlessness and to Faustus himself, whom he also addresses as 'great'. The sweetness is in direct difference to the revoltingness of Faustus' wrongdoings; and, when connected to himself, it shows that the Old Man holds his confidence in Faustus as a spirit who may yet be reclaimed.

Faustus, however, fails to respond to the Old Man's plea, and asks him to leave him alone "to ponder on my sins." $(12,50)$ Dismissing the earnest endeavors of ilham, he swings to "sweet Helen". He is cognizant that Faustus has played Judas on atonement. He is then assaulted by various devils, whom he resists by his turn towards God, underlining the quality that he picks up from his confidence:

Ambitious fiends, see how the heavens smiles

At your repulse, and laughs your state to scorn (Scene 12, 115-116).

As soon as the Old Man leaves, and Mephistopheles returns and threatens Faustus, Faustus regresses to his servitude to the devil:

\section{Mephistophilis}

Thou traitor, Faustus: I arrest thy soul For disobedience to my sovereign lord. Revolt, or I'll in piecemeal tear thy flesh.

\section{Faustus}

Sweet Mephastophilis, entreat thy lord To pardon my unjust presumption; And with my blood again I will confirm My former vow I made to Lucifer. $* * *$

Torment, sweet friend, that base and crooked age

That durst dissuade me from thy Lucifer, With greatest torments that our hell affords. (12, 57-63, 66-68)

Mephastophilis' answer is to a great degree fascinating, in light of the fact that it accentuates his shortcoming when he experiences a genuinely trusting Christian:

His faith is great, I cannot touch his soul,

But what I may afflict his body with
I will attempt - which is but little worth

(Scene 12, 77-79).

The Old Man as ilham symbolizes the incorporated social result of faith in primary hypotheses. Christ and God symbolize the primary hypotheses themselves. The decrepitude of the Old Man - "that base and crooked age" reflects Faustus's poor opinion of the chances of survival of the society for which the Old Man stands.

Therefore, Faustus does not appeal to the Old Man's Christ but to his own individualist, scapegoat Christ. In order to keep his pledge to the devil, Faustus asks Mephistopheles to bring him "That heavenly Helen which I saw of late". (12, 75) Helen's is that essentially destructive beauty which has "burnt the topless towers of Ilium"; $(12,82)$ the "immortality" she provides with her kiss is the absolute antithesis of all truth, morality, and religion. When Faustus says: "Her lips sucks forth my soul, see where it flies!/ Come Helen, come, give me my soul again./ Here will I dwell, for heaven be in these lips, /And all is dross that is not Helena!", (12, 84-87) Faustus speaks of heaven, yet we know that it is really hell he speaks about, though unaware. He asks that Helen make him "immortal with a kiss," (12, 83 ) but in reality he is asking for the coup de grace that will irrevocably damn him. Helen is a devil in female guise, a succuba, and Faustus, in receiving her "immortal kiss," "commits the sin of demoniality".

The Old Man aptly describes Faustus as a "miserable man" $(12,101)$ because, "though a real heaven is 'all about him where to choose,' he seeks it rather in a phantasm". He also spends his last hour in prospection of damnation and phantasms of salvation which cannot be realized because he lacks the faith and trust in God necessary to achieve them. $\mathrm{He}$ is unavoidably unequipped for hearing the two sides of confidence's mystery; he can hear just the reas on of Sin, not the conclusion of Redemption:

\section{Faustus}

But Faustus' offence can ne'er be pardoned! The serpent that tempted Eve may be saved, but not Faustus....

\section{3 scholar}

Yet Faustus, call on God.

\section{Faustus}

On God, whom Faustus hath abjured? On

God, whom Faustus hath blasphemed? Ah 
my God - I would weep, but the devil

draws in my tears! (13, 15-16, 27-30)

McCloskey argues that Faustus cannot repent because of the sin of despair. It is his own Medusa, his Gorgon of Despair, lurking within the dark alleys of his ambition and pride which has changed his heart into stone and made him unable to repent and ask forgiveness. Faustus cannot see God as the merciful and benevolent creator and giver of life, but rather a vengeful deity bent on punishing him:

\section{see where God}

Stretcheth out his arm, and bends his ireful brows!

Mountains and hills, come, come and fall on me,

And hide me from the heavy wrath of God. ...

My God, my God, look not so fierce on me! (13, 76-77; 112)

The last discourse turns around the first. The glad researcher who had worried at the confinements forced by the human condition and yearned for the everlasting status of a divine being presently looks to evade an unending length of time of condemnation. Like a caught creature he lashes out against the work he has woven for himself, and turns out to be increasingly entrapped. To be physically consumed, to be 'an animal needing soul', 'some brutish monster', even, at the last, to be close to 'little water drops' this is the last any desire for the pride of Wittenberg. The play closes with Faustus hauled to damnation alive by fallen angels.

\section{2 "Half of him is of the angel and half of him is ass."}

An established view in Islamic discourse is that human instinct comprises of five components what Gazaly terms as the five fighters. The two officers of outrage/sense of self and sexual energy can be guided by the heart totally or then again resist and agitator against it totally, until the point that they subjugate it. In that lies the passing of the heart and the end of its voyage towards endless joy. Different warriors are: information ('ilm), insight (hikma) and reflection (tafakkur) whose assistance a human looks for by appropriate, for they are the Party of God against the other two who have a place with the gathering of shaytan.

Faustus plainly ignores (ilm), (hikma) and (tafakkur) engaging his sense of self and sexual enthusiasm. Allah (swt) says: "Seest thou such a one as taketh for his god his own passion (or impulse)?"( The Quran 25:43) and "but he inclined to the earth, and followed his own vain desires. His similitude is that of a dog: if you attack him, he lolls out his tongue, or if you leave him alone, he (still) lolls out his tongue. That is the similitude of those who reject Our signs; So relate the story; perchance they may reflect" (The Quran $7: 176)$. The person who controlled the passion of his ego Allah swt says:
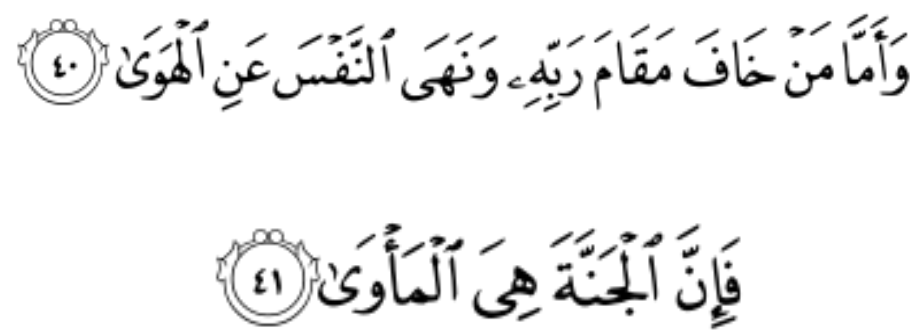

And for such as had entertained the fear of standing before their Lord's (tribunal) and had restrained (their) soul from lower desires, Their abode will be the Garden. (The Quran 79:40-41)."

During Christopher Marlowe's time and for centuries before then, "lechery," or lust/desire, was considered one of the "seven deadly sins." In fact, Lechery appears as a character in Marlowe's play Doctor Faustus in precisely that capacity. Lechery was traditionally defined as a selfish desire to use the body of another person to achieve self-centered pleasure. Lechery could also involve idolizing the body of another person and thus turning away from proper worship - the worship of God.

The clearest example of Doctor Faustus's own lechery appears when he asks Mephastophilis to revive and bring before him the beautiful body of Helen of Troy, the woman whose own lust and infidelity were traditionally blamed for the horrors of the Trojan War described in Homer's epic poem The Iliad. Interestingly, Faustus deliberately asks to see Helen so that he will not be distracted fro $m$ his demonic commitments. An Old Man has just tried to win him back to the worship of God; Faustus tries to use Helen as an antidote to counteract the Old Man's persuasiveness.

When "Helen" appears, Faustus not only idolizes her but expresses lust for her:

Sweet Helen, make me immortal with a kiss:

Her lips sucks [sic] forth my soul, see where it flies!

Come Helen, come, give me my soul again.

Here will I dwell, for heaven be [sic] in these lips ... 
These lines are ironic in numerous ways. In the first place, only God can make Faustus "immortal." Secondly, Helen does not literally suck forth Faustus's soul; instead, Faustus himself has voluntarily sold his soul to Satan. Thirdly, Helen has no power to return Faustus's soul to Faustus; only God can do that if Faustus sincerely repents of his bad bargain with Satan. Fourthly, when Faustus says that heaven is in Helen's lips, he is either exaggerating or is deceiving himself. Heaven is where it's always been (with God), but Faustus's phrasing indicates just how much lechery is entangled with idolatry. Yet this kind of idolatry is ultimately rooted in self-love, not true affection for another person. It seems significant that Helen never has a chance to speak a word in response to Faustus's hyperboles. She matters to him only as a means of satisfying his own selfish desires.

Another narrative in Is la mic discourse investigates that God made the angels from reason without animalistic want and He made people from the mix of these two. Therefore, whoever uses his reason above his desire is superior to the angels and whoever uses his desire above his reason is inferior to the four-footed ones.

Indicating this Jalāl ad-Dīn Muhammad Balkh̄̄ [ar-Rūmī] presents in this manner

It is related in the hadith that the Majestic God Created the creatures of the world (in) three kinds. One class (He made) entirely reason and knowledge and munificence;

That is the angel: he knoweth naught but prostration in worship.

In his original nature is no concupiscence and sensuality:

He is absolute light, (he is) living through (his) love of God.

Anotherclass is devoid of knowledge, Like the animals (which lives) in fatness from (eating) fodder.

It sees nothing but stable and fodder:

It is heedless of (future) misery and glory (felicity).

The third (class) is Adam's descendant and Man:

Half of him is of the angel and half of him is ass. (qtd in Islami 27)

This is the condition of human presence. His common viewpoint guides him to the world while his divine side goads him to mission and development
The late Farīdūn Mashīrī, a contemporary Iranian writer relates this status of man, subsequently:

A wise man said: A stubborn wolf Is hidden inside every man.

Inevitably, there is a great conflict and war

That takes place day and night between the man and the wolf.

Men are at logger head with each other

And these wolves lead and direct them.

For, this man is ill and ill-fated;

As such, the wolves rule over them.

Those tyrants are together;

Thus, their wolves are friends to one another.

The wolves are together while men are far from one another.

To whom should we share this amazing condition? (qtd in Islami 31-32)

Faustus's Wolf is his passionate or overmastering craving for intense sexual desire or appetite. At the point when Mephistopheles expresses that "I'll bring them every morning to thy bed", Faustus echoes this expressing "I am wanton and lascivious and cannot live without a wife." And he wants "sweet Helen", to "make" him "immortal with a kiss."

Faustus isn't a nonpartisan observer of his internal war with the 'wolf'; rather, he resembles an authority who, by the decision he makes, acts to the advantage of one of the sides in the war. Man does appreciate the privilege to pick, as well as obliged to pick. If there should be an occurrence of Faustus he picks the "stubborn wolf" to be his lord.

Faustus neglects to fit in the Gazali's moral story that body resembles a town and the astuteness of the develop person resembles a ruler deciding that town. Every one of the powers of the outer and interior detects he can ace resemble his warriors and his associates. The sense of self that charges abhorrent (nafs ammara), that is, desire and outrage, resembles a foe that difficulties him in his kingdom and endeavors to butcher his kin. The body subsequently winds up noticeably like an army town or ocean station, and the spirit like its overseer posted in it. In the event that he battles against his foes and thrashings them and constrains them to do what he prefers, he will be applauded when he comes back to God's essence, as Allah swt says: "those who strive in the way of Allah with their wealth and lives. Allah hath conferred on those who strive with their wealth and lives a rank above the sedentary" (The Quran 4:95). 


\section{FRIEND: A POTENTIAL ENEMY}

Fellowship and camaraderie are vital in Islam. A decent companion is one who acknowledges our deficiencies, however in the meantime aides and backings us. A decent companion is one who obliges our shortcomings however amends them where conceivable. A decent companion is one who will love and pardon you for God.

Faustus' punishment was tied down by his underhanded companions Valdes and Cornelius whom he terms as 'my dearest friends'. They are now honing performers and they have unmistakably had past discussions with Faustus, influencing him to 'practice magic and concealed arts' (1, 102). They show the advantages of their craft particularly as far as power and notoriety, particularly in Valdes' discourse starting: "Faustus, these books, thy wit, and our experience / Shall make all nations to canonize us" $(1,119-120)$. They plainly would like to enlist Faustus to build their own energy - there are a few references to what they may accomplish together. The motivation of his companions and his unquenchable push for control move him to be "violated" by enchantment.

That is the reason Islamic discourse gives much significance on picking companions precisely. Prophet Muhammad (saws) cautioned the devotees about this as well. He said that a man would be affected by his companions, and he cautioned that everybody should take a gander at those they consider to be their friends.

What we can comprehend from this is it is anything but difficult to be affected by the general population around us. It is anything but difficult to go up against their idiosyncrasies and qualities without monitoring it. In the event that these are great qualities then it really is ideal however imag ine a scenario in which the general population you consider companions have pushed you far from the recognition of God. This could be a debacle, and God cautions about it in the Quran:

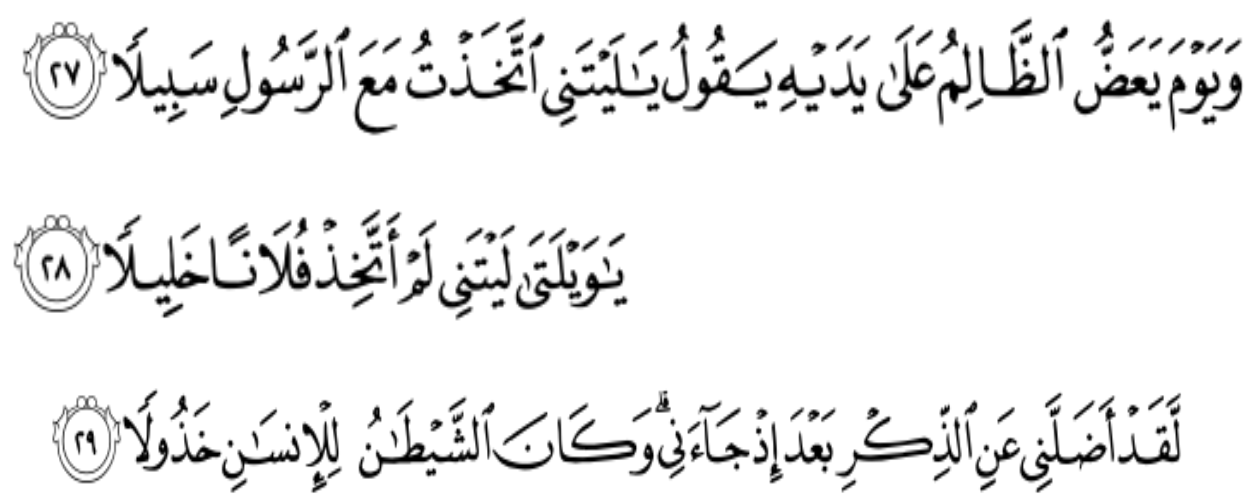

The Day that the wrong-doer will bite at his hands, he will say, "Oh! would that I had taken a (straight) path with the Messenger! Ah! woe is me! Would that I had never taken such a one for a friend! "He did lead me astray from the Message (of Allah) after it had come to me! Ah! the Evil One is but a traitor to man!" (The Quran 25:27-29)

Prophet Muhammad (䋨) also echoed this point when he told the story of the blacksmith and the perfume seller.

The example of a good companion (who sits with you) in comparison with a bad one, is like that of the musk seller and the blacksmith's bellows (or furnace); from the first you would either buy musk or enjoy its good smell while the bellows would either burn your clothes or your house, or you get a bad nasty smell thereof. [ Saheeh Al-Bukhari, Vol. 3, Book 34, Hadith 314)

\section{IS ANY CRIME TOO BIG TO BE FORGIVEN?}

Seeing that Doctor Faustus is a Christian play, it manages the topics at the core of Christianity's comprehension of the world. To begin with, there is sin, which Christianity characterizes as acts in opposition to the desire of God. In making an agree ment with Lucifer, Faustus submits what is one might say a definitive sin: in addition to the fact that he disobeys God, yet he intentionally and even anxiously disavows submission to him, picking rather to swear faithfulness to the fiend. In a Christian structure, in any case, even the most noticeably awful deed can be excused through the redemptive intensity of Jesus Christ, who, as indicated by Christian conviction, passed on the cross for mankind's transgressions. Along these lines, anyway horrendous Faustus' agreement with Lucifer might be, the likelihood of recovery is constantly open to him. All that he needs to do, hypothetically, is approach God for pardoning. The play offers endless minutes in which 
Faustus considers doing only that encouraged on by the great blessed messenger on his shoulder or by the Old Man in Scene 12.

Each time, Faustus chooses to stay faithful to hellfire as opposed to look for paradise. In the Christian system, this getting some distance from God sentences him to spend an unending length of time in damnation. Just toward final stage of his life does Faustus want to apologize, and, in the last scene, he shouts out to Christ to recover him. Be that as it may, it is past the point of no return for him to atone. In making this minute in which Faustus is as yet alive however unequipped for being recovered, Marlowe ventures outside the Christian perspective so as to augment the emotional intensity of the last scene. Having occupied a Christian world for the whole play, Faustus spends his last minutes in a somewhat unique universe, where recovery is never again conceivable and where certain wrongdoings can't be pardoned.

Islamic discourse has something else to say about Marlowe notion of salvation. The essence of Islamic view of mercy and hope is "truly no one despairs of Allah's Soothing Mercy, except those who have no faith." (The Quran, 12: 87). While in Marlowe's universe some offences are at times unpardonable:"But Faustus' offence can ne'er be pardoned! The serpent that tempted Eve may be saved, but not Faustus. ..." (13, 15-16, 27-30), and "Accursed Faustus, where is mercy now?/I do repent; and yet I do despair:/Hell strives with grace for conquest in my breast:/What shall I do to shun the snares of death?", Is lam on the other hand puts forward the question whether there is any sin that cannot be pardoned.
Islamic notion of God and God's rahmah (mercy) is quite unique. In a Hadith-e-Qudsi, Allah swt has said:

O son of Adam, so long as you call upon $\mathrm{Me}$ and ask of Me, I shall forg ive you for what you have done, and I shall not mind. O son of Adam, were your sins to reach the clouds of the sky and were you then to ask forgiveness of Me, I would forgive you. O son of Adam, were you to come to Me with sins nearly as great as the earth and were you then to face Me, ascribing no partner to $\mathrm{Me}$, I would bring you forgiveness nearly as great as it. (40 Hadithe Qudsi, Hadith no. 34)

Quranic God is described as the most Forgiving. There are many names of God given in the Qur'an which are related to His mercy and forgiveness. Some of them are: Al Ghafoor, The Most Forgiving(this name occurs in the Qur'an more than seventy times);Al-'Afuw meaning "to release" "to heal", "to restore", "to remit" (this name occurs in the Qur'an five times); Al-Tawwab, the Acceptor of repentance (this name of Allah is mentioned in the Qur'an about 11 times); Al-Rahman and al-Rahim, the most Merciful and Compassionate (Al-Rahman is mentioned 57 times and Al-Raheem is mentioned 115 times ).

Opposed to the unpardonable version of sin of the Faustian Universe where Faustus cannot see God as the merciful and benevolent creator and giver of life, but rather a vengeful deity bent on punishing him, Islamic version of God, Allah swtwith an assurance of mercy has given a unique invitation to all the people to turn towards Him and seek forgiveness for their sins:

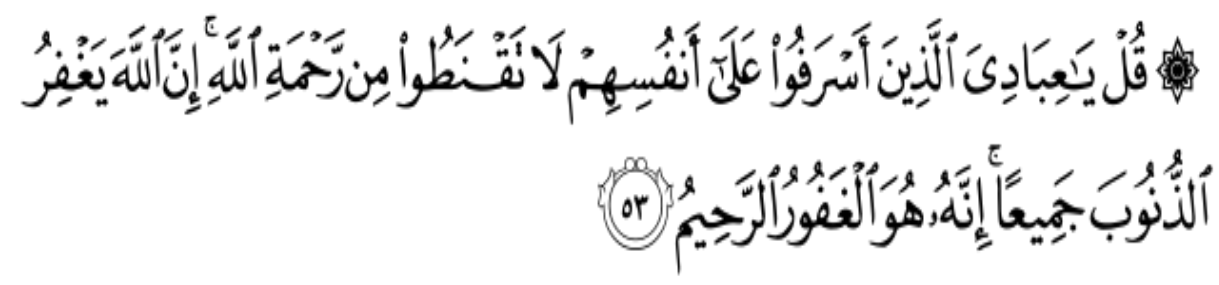

Say: "O my Servants who have transgressed against their souls! Despair not of the Mercy of Allah: for Allah forgives all sins: for He is Oft-Forgiving, Most Merciful. (The Quran 39:53).

Allah's Messenger( (淽) said:

When Allah created the creation as He was upon the Throne, He put down in His Book: Verily, My mercy

predominates My wrath (bold added, Sahih Muslim, Book 37, Number 6626).

Allah's Messenger (

Allah, the Exalted and Glorious, said: I live in the thought of My servant and I am with him as he remembers Me. (The Holy Prophet) further said: By Allah, Allah is more pleased with the repentance of His servant than what one of you would do on finding the lost camel in the waterless desert. When he draws near Me by the span of his hand. I draw near 
him by the length of a cubit and when he draws near Me by the length of a cubit. I draw near him by the length of a fathom and when he draws near Me walking I draw close to him hurriedly. (Sahih Muslim, Book 37, Number 6610).

Faustus' ass ertion "I do repent; and yet I do despair" is what might drive towards uttermost frustration. Is la mic d iscourse makes it pretty clear that after 'Shirk' no wrongdoing could be more noteworthy than to despair of Allah's (Swt) mercy and generosity. This frame of mind decreases an individual to a condition of absolute sadness. He envisions himself to be bound for Hell, and thusly he sees no advantage in doing great and staying away from shrewdness. Subsequently he endeavors to accomplish however much common delight as could reasonably be expected and along these lines gets additionally engaged with a wide range of wicked acts. Some other kind of miscreant could be acquitted on the off chance that he apologizes. Yet, the person who gives up does not have the right to be exculpated on the grounds that the psychological state of such an individual does not lead him towards apology, yet rather, initiates him to keep on submitting further demonstrations of transgression against Allah's directions

\section{CONCLUSION}

Marlowe's Dr Faustus is about a scholar's bargaining with the Lucifer in exchange of his nafs and the play leaves us with the protagonist's nafs's (soul) last night struggle which he goes in a discourse of anguish and yearning, amid which Faustus sees what paradise implies. The dramatization of the unending conflict between good and evil has primarily been shown by the presentation of the Good Angel (ilham) and Band Angel (waswasa). Throughout the play Faustus plainly ignores 'ilm, hikma and tafakkur engaging his sense of self and sexual enthusiasm.Faustus's Wolf is his passionate or overmastering craving for intense sexual desire or appetite. He failed to make a decent companion who will love and pardon him for God. Finally, in Marlowe's universe some offences are at times unpardonable: "Accursed Faustus, where is mercy now?/I do repent; and yet I do despair:", Islam on the other hand puts forward the question whether there is any sin that cannot be pardoned. The essence of Islamic view of mercy and hope is "No one despairs of God's soothing mercy except those who have no faith" (Quran, 12: 87)".

\section{REFERENCES}

[1] Ahmed, Mohammad Kaosar. "The Turn to Islamic Ways in Teaching English Literature." Reading Shakespeare from Islamic Perspective. Dhaka:
Bangladesh Institute of Islamic Thought, 2014. 1-12. Print.

[2] Ahmed, Mohammad Kaosar. "Islamic Discourse in Shakespearean Study: Teaching Shakespeare from Islamic Perspective - Worksheet on Macbeth". Reading Shakespeare from Islamic Perspective. Dhaka: Bangladesh Institute of Islamic Thought, 2014. 17-82. Print.

[3] Ahmed, Mohammad Kaosar. "Perspectives on the Discourse of Islamization of Education." American Journal of Humanities and Social Sciences, vol. 2, no. 1, 2014, pp. 43-54. Web.

[4] Ghazali, Imam. Ihya' 'Ulum ad-Din [The Revival of the Religious Sciences]. Cairo, Al-Matba'a alAzhariya, 1898 (A.H. 1316). 4 vols.

[5] Islami, SayyidHasan. Imam Khomeini, Ethics and Politics. The Institute for Compilation and Publication of Imam Khomeini's Works, 2002.

[6] Marlowe, Christopher. 'Doctor Faustus,' A-and BTexts (1604, 1616). Eds. David Bevington and Eric Rasmussen. Manchester: Manchester UP, 1993. Print.

[7] McClosky, John C. "The Theme of Despair in Marlowe's Faustus", College English 4: no. 2 (Nov., 1942), 110-113.

[8] Sahih Muslim.Sunnah.com, Sunnah Foundation, sunnah.com/muslim. Web.

[9] Sahih al-Bukhari.Sunnah.com, Sunnah Foundation, sunnah.com/bukhari. Web.

[10] Sunan Ibn Majah.Sunnah.com, Sunnah Foundation, sunnah.com/ibnmajah. Web.

[11] 40 Hadith Qudsi.Sunnah.com, Sunnah Foundation, sunnah.com/qudsi40. Web. 